\title{
Design Sprint Methods for Developing Mobile Learning Application
}

\section{Herry Sumual, Johan Reimon Batmetan, and M. Kambey}

Information Technology and Communication Education Department, Universitas Negeri Manado, Tondano, 95618, Indonesia

\section{Abstract}

Mobile learning has become an alternative in the learning model. It uses smartphones as a basis for running applications so learning content can be accessed using a smartphone. Many mobile learning applications have been created but only a few are used because the appearance and features are not attractive to users. It is very important to design mobile learning applications specifically because smartphones still have limitations in running various applications. This study aims to examine the techniques of designing mobile learning applications quickly, easily, and cheaply according to users' needs. The method used in this study is the method of design

Corresponding Author: Johan Reimon Batmetan john.reimon@unima.ac.id

Received: 11 January 2019 Accepted: 14 February 2019 Published: 25 March 2019

Publishing services provided by Knowledge E

(c) Herry Sumual et al. This article is distributed under the terms of the Creative Commons

Attribution License, which permits unrestricted use and redistribution provided that the original author and source are credited.

Selection and Peer-review under the responsibility of the 3rd ICTVET 2018 Conference Committee.

\section{G OPEN ACCESS} sprint method which is a fast design model for building applications effectively and efficiently. The results of this study indicate that designing using the Design Sprint Methods model can engineer smartphone-based software easily and quickly. This model can significantly reduce weaknesses in making mobile learning applications. The results of this study also suggest that this model can formulate ideas successfully and creatively to build mobile learning applications. In conclusion, this model is very well used in building mobile learning applications easily and can be implemented quickly.

Keywords: design sprint methods, higher education, mobile learning, prototype, validation

\section{Introduction}

Mobile learning has become an alternative in the learning model. Mobile learning uses smartphones as a basis for running applications so learning content can be accessed using a smartphone. Data from the Ministry of Communication and Information Technology in the last 3 years shows a significant increase in the number of users. In 2014, the number of internet users in Indonesia reached 82 million people. Increasing in 2016 reached 132.7 million people and in 2017 it reached 143.26 million people [1]. The data also shows that the most productive age users of the internet in Indonesia are currently used by students who reach $89.7 \%$. Smartphone user data in Indonesia 
also shows a significant increase, which has reached 63.1 million people $(47.6 \%)$ of the Indonesian population [2]. Mobile devices such as smartphones and tablet PCs can be used in accessing mobile learning media, which has increased in terms of the type of Internet content accessed in education, reaching 124.4 million people, equivalent to $93.8 \%$ [3]. This shows that mobile phones have become the device most often used by students to access learning content. Thus the smartphone is the best choice for mobile learning applications. It is very important to build a smartphonebased learning application design so that it becomes mobile learning. Mobile learning can help users access learning with an easy-to-use, easy-to-learn display, simple and useful appearance [4].

Mobile learning is the development of e-learning by paying attention to the advantages of more mobile resources, fast and powerful search capabilities because it uses a more flexible cellular telecommunications network, rich interaction, strong support for effective learning, and performance- based assessment[5]. Mobile devices such as telephone and tablet PCs can be used to access mobile learning media. M-learning allows for more opportunities to interact indirectly between users (students) and teachers (lecturers)[6]. m-learning is also a learning media where users (students) can access learning material wherever and whenever so that it can increase user attention to learning material and encourage learning motivation[3]. The type of e-learning that distributes learning content and supporting material that uses communication tools wireless is called M-learning.

Mobile learning uses smartphones as a basis for running applications so learning content can be accessed using a smartphone. Many mobile learning applications have been created but only a few are used because the appearance and features are not attractive to users. It is very important to design mobile learning applications specifically because smartphones still have limitations in running various applications. This study aims to examine the techniques of designing mobile learning applications quickly, easily and cheaply according to users' needs.

\section{Methods and Equipment}

\subsection{Methods}

This study uses the Design Sprint method which is a creative and practical way of thinking in solving problems or work. The Design Sprint method is a creative method that can build an application quickly and easily[7, 8]. The stages begin by collecting 
data obtained from the interview process of 150 mobile learning users. These users are lecturers and students who routinely use mobile learning continuously. In addition, researchers also made observations to find out the activities that users have and how they use mobile learning in the higher education learning process. Each sprint goes through the 6 stages of design thinking. The idea of Design Thinking was created at IDEO and expanded through the Design School at Stanford. It's incredibly useful for solving problems. See Figure 1.

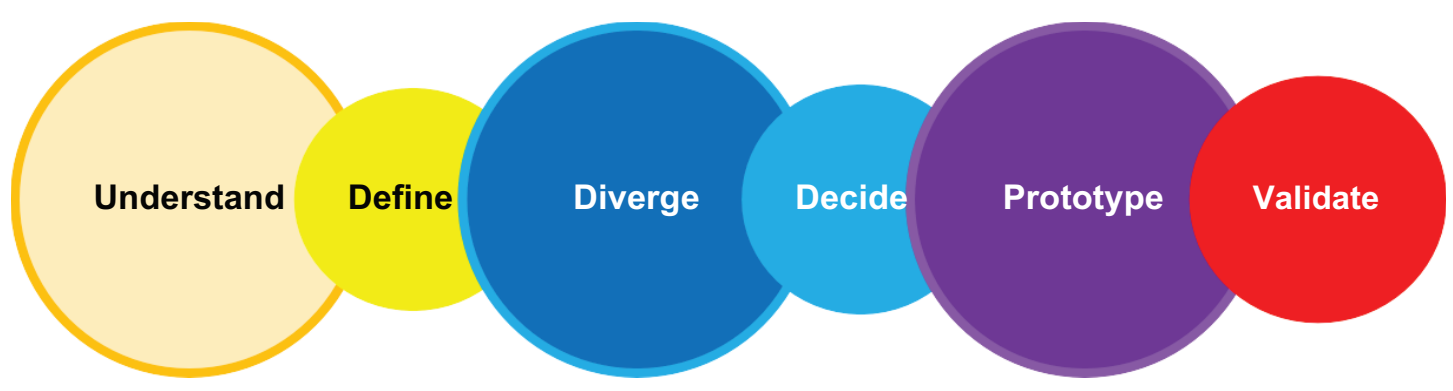

Figure 1: The six stages of design Sprint.

Understand: What are the user needs, business need and technology capacities? The stages in which we observe what the user is doing and how they interact with their environment are directly involved in helping to express their thinking and values, after observing and involving themselves with the user, it is also important to experience the user experience directly. Define: What is the key strategy and focus? At this stage we determine problems that focus on the user that is specific and based on insight and user needs. Diverge: How might we explore as many ideas as possible? Issue opinions or ideas that can be a solution to the problem. Decide: Select the best ideas so far. At this stage, the voting process of the best ideas and designs will be carried out. Prototype: Create an artifact that allows you to test the ideas with users. Applying ideas that have been collected in physical form, can be notes posted on walls, objects, or even storyboards. Validate: Test the ideas with users, business stakeholders and technical experts. This stage is also carried out a test to improve the solution and make it even better.

\section{Results}

\subsection{Understand}

Based on the discussion found several main problems found in the learning process, namely the appearance of mobile learning applications that are very difficult to understand, so that when the process of distributing material still using flash can slow down 
the teaching-learning process because it must be copied one by one, giving and collecting tasks that are still done manually or in print can eat a lot of costs so we want to solve the above problem by creating a mobile learning application that can be useful[9]. there have been many mobile learning applications produced but there are still few who use the application because there are several problems or obstacles found[10].

Researchers conducted interviews from stakeholders, namely lecturers and students and found out the constraints and problems that are often found in the use of mobile learning applications so that it can be a reference for us to create applications that can be useful. Problems that are often experienced can be seen in Figure 2 below:

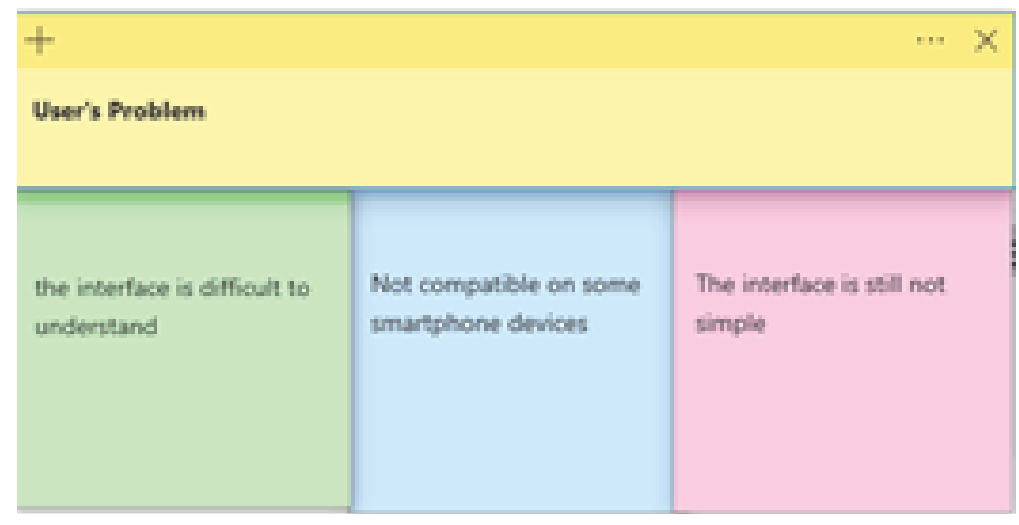

Figure 2: User's problem.

The results of observations on the user found that the learning process carried out anywhere when there were no lecturers, some students just stayed silent and did not learn because there was no material given or assignments given when the lecturer was outside the area and there were also some students who came to campus only to take material so that it can hamper the learning process. Lecturers also do not provide digital learning material, so the learning process stops when they do not face to face directly[11]. Therefore, a mobile learning application is needed that can help the learning process become faster and can be implemented, can be accessed anywhere and anytime[12, 13] with a simple appearance.

\subsection{Define}

The results of this study found that user experience when using mobile learning applications requires solving problems faced quickly and accurately. Researchers begin by collecting and identifying user needs if using mobile learning. These needs are mapped in the following picture. The user needs are arranged in a systematic and 
structured manner[14]. Then a map of the needs was tried to create a design that the user wanted[15]. User needs are made in summary by using a sticky note tool like the picture below: The requirement of users can be indented by the need for chat / live message features, learning media that can be accessed offline, language enhancements, notifications for task notifications, material uploads and downloads, download history, assigning values to tasks that have been done, features for examinations and quiz.

\subsection{Diverge}

At this stage the research team made a rough design of the mobile learning application storyboard[16] that would be made according to the needs and problems that had been encountered above, the team made two design designs which would later be voted by stakeholders, the design as below:

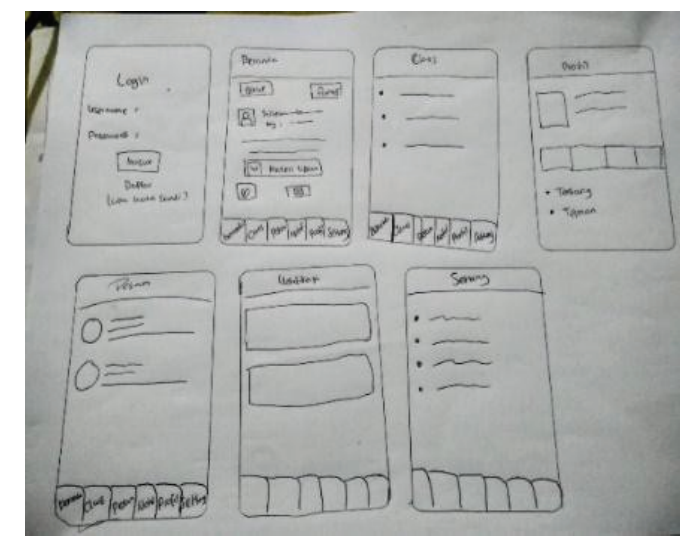

(a)

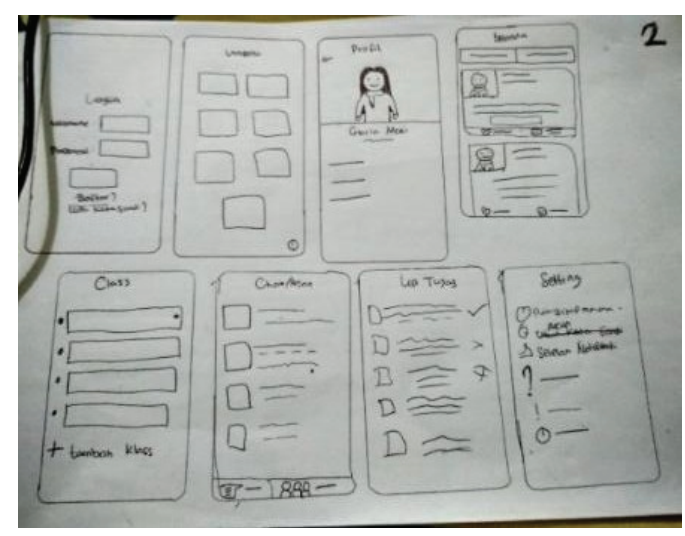

(b)

Figure 3: Design pra interface.

Figure 4 (a) is the 1st choice image as an alternative design while Figure 4 (b) is the 2nd alternative that is made to be able to choose which is more suitable to be used in designing the application with the next step.

\subsection{Decide}

The decision process is made by voting. Voting is done after the sketch is made, voting is done by pasting the two sketches on the board and encouraging some people to vote for the sketch they want.

After voting, the research team discussed and reviewed the most voting options that will be used as a reference for the design of mobile learning applications. see Figure 


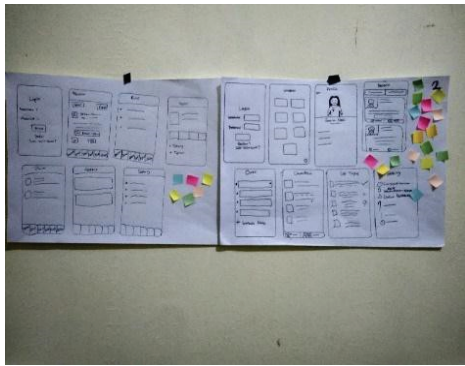

(a)

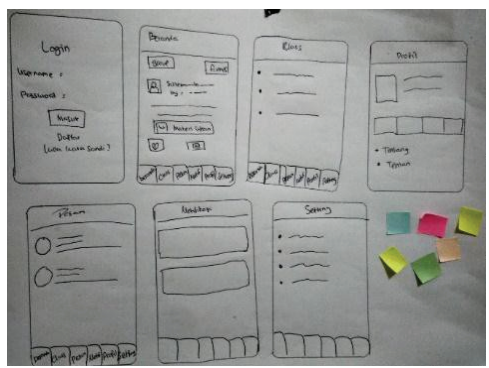

(b)

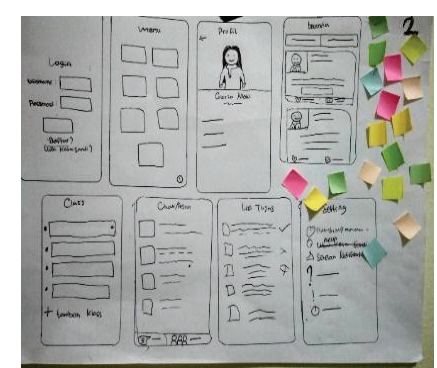

(c)

Figure 4: Voting design interface.

4(a). Researchers found that the second choice had the most votes, namely 18 votes (see Figure 4(c)) and choice 1 got 6 votes (see Figure 4(b)). Thus, option 2 is the basis for creating a mobile learning application and proceed to the next stage. The next stage in this state is Thinking Hat[17], At this stage, the researcher discusses the decisions that have been taken and devotes each other to the next design stage in the second display design that has been chosen by the user.

\subsection{Prototype}

After going through the stages of deciding, researchers then build a mobile learning prototype. This stage is passed by building a prototype according to user needs and application details that have been made previously on the storyboard[18]. Some interfaces that are built can be seen in the following Figure 6 to 14 .

In Figure 6, displays the interface used for login, according to the username and password that have been registered. If you have not registered then the user can do the signup process first. In Figure 7, is the main menu that provides the main features of the application, users can directly access the existing menu according to their activities. In Figure 8, is a home menu, where users can see what classes are being followed and what learning material is available, users can also see their friends in the same class. Figure 9 is a menu profile of the user where the user can do activities such as editing, and setting up the account. In Figure 10, it is an interface that can be used by the user to choose which classes are available which will follow the learning in that class. Figure 11 , users can see what material files have been downloaded and can be used. Figure 12 , is an interface that can be used by users to chat to instructors or other users. Figure 13 , is an interface to see what notifications are given by the system to the user so that the user can respond with the next activity. Figure 14, is an interface that can be used to set up on the user's own account. 


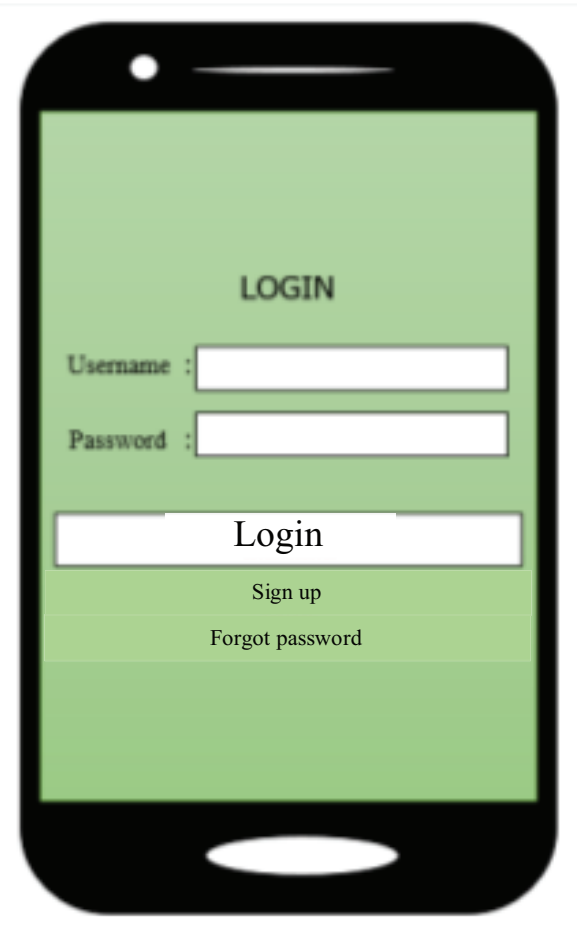

Figure 5: Interface Login.

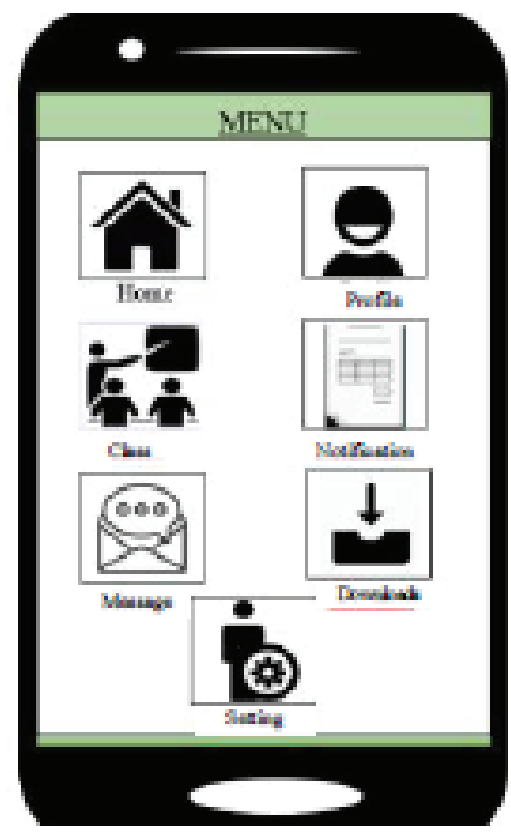

Figure 6: Interface Menu.

\subsection{Validate}

At this stage, the researcher managed to do the test by showing the results of the prototype that had been made and the appearance of the existing design. Researchers also provide an opportunity for users to try using application simulations that have 


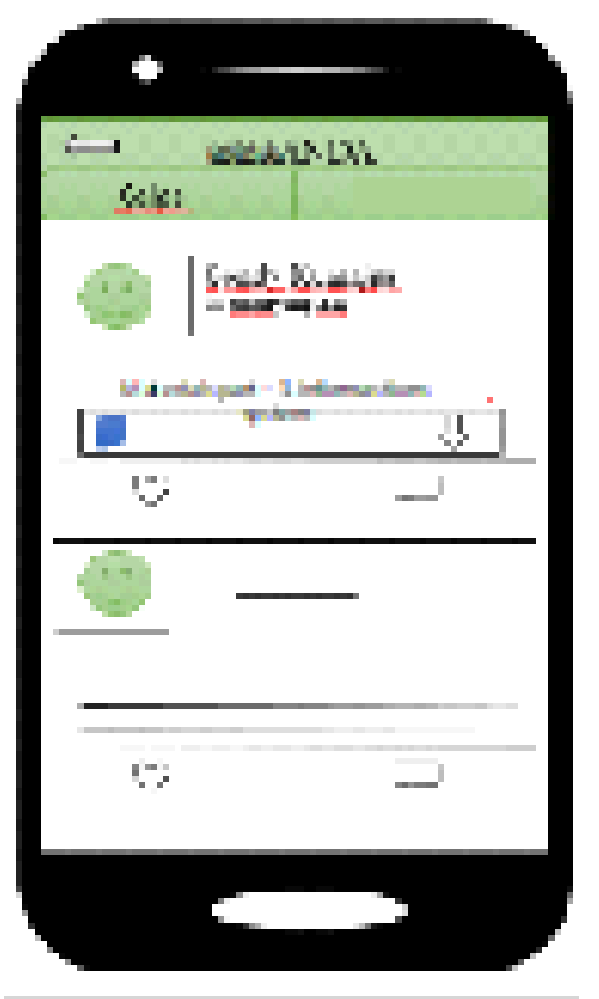

Figure 7: Interface Home.

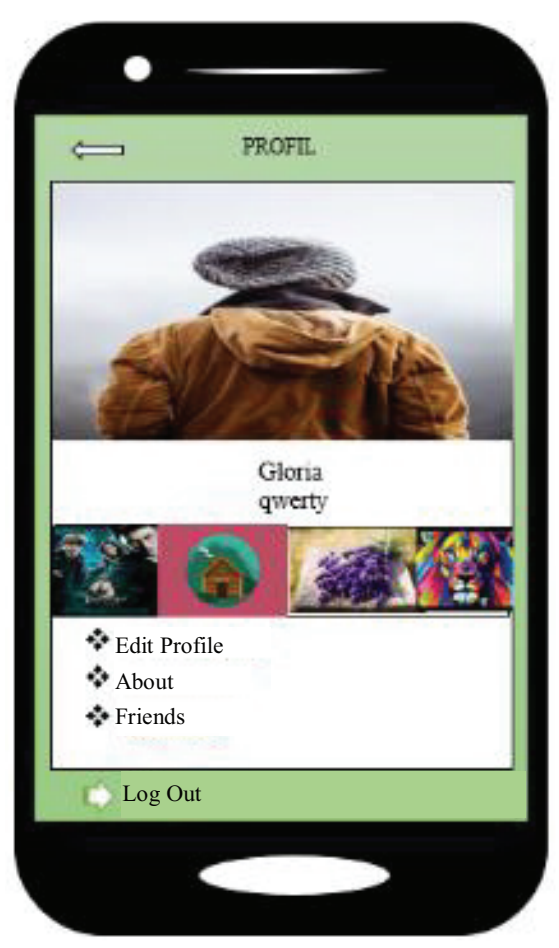

Figure 8: Interface profile.

been made[19]. The results show that $90 \%$ of users really like to use this application. The results also show $92 \%$ of users stated that the display is easy to use, $94 \%$ stated 


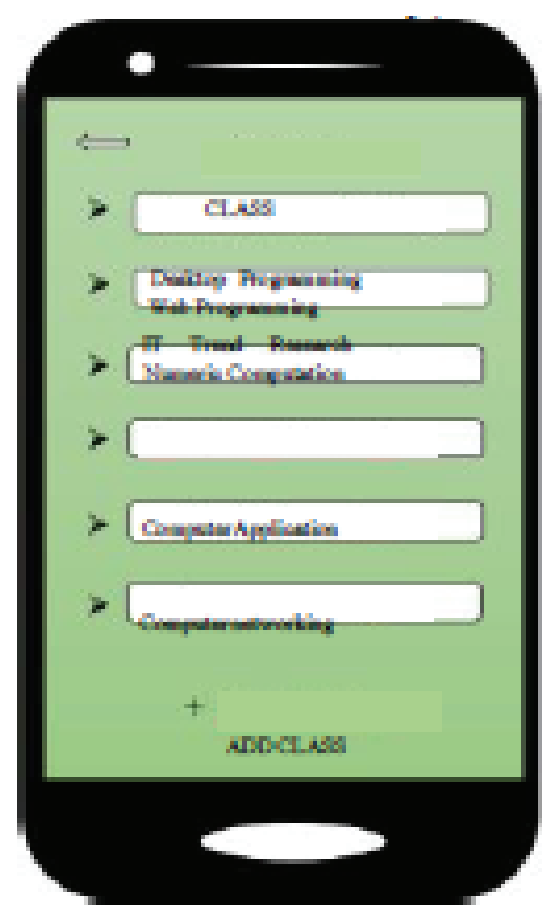

Figure 9: Interface Class

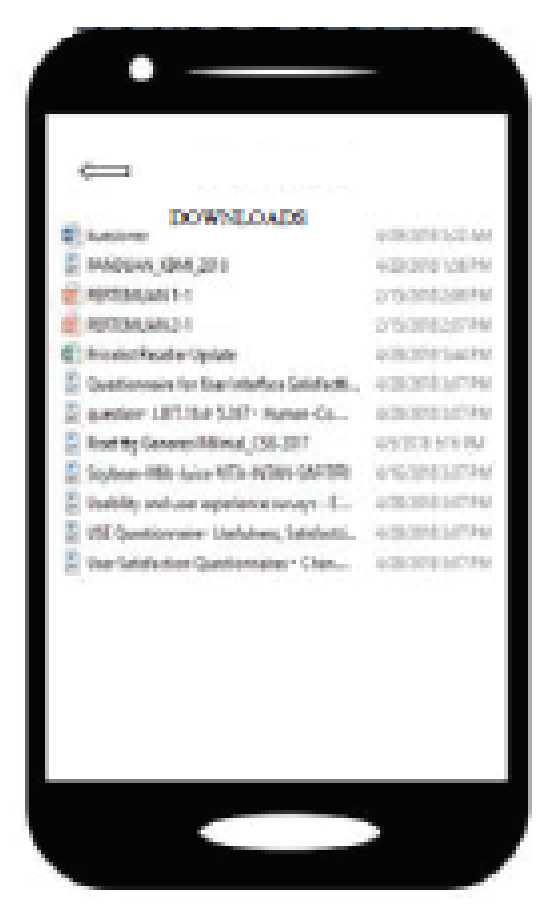

Figure 10: Interface download.

that the mobile learning application is easy to learn, 92\% stated that the application has a simple appearance and $90 \%$ stated that this mobile learning application was very useful. 


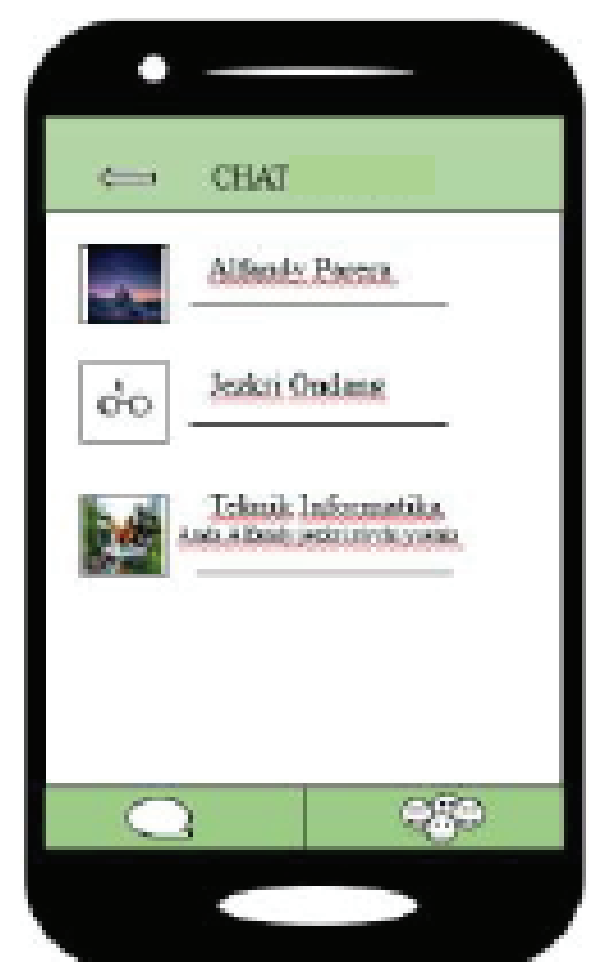

Figure 11: Interface Chat.

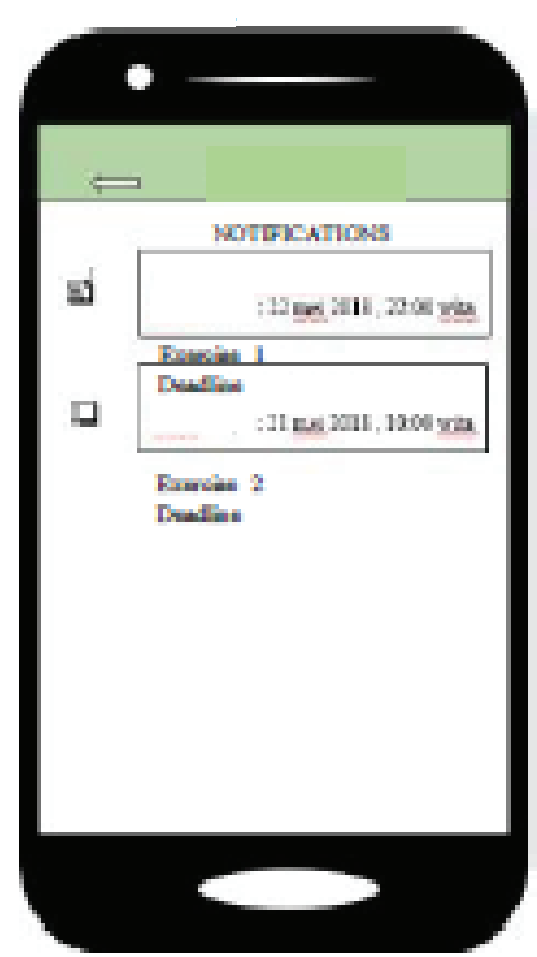

Figure 12: Interface notification. 


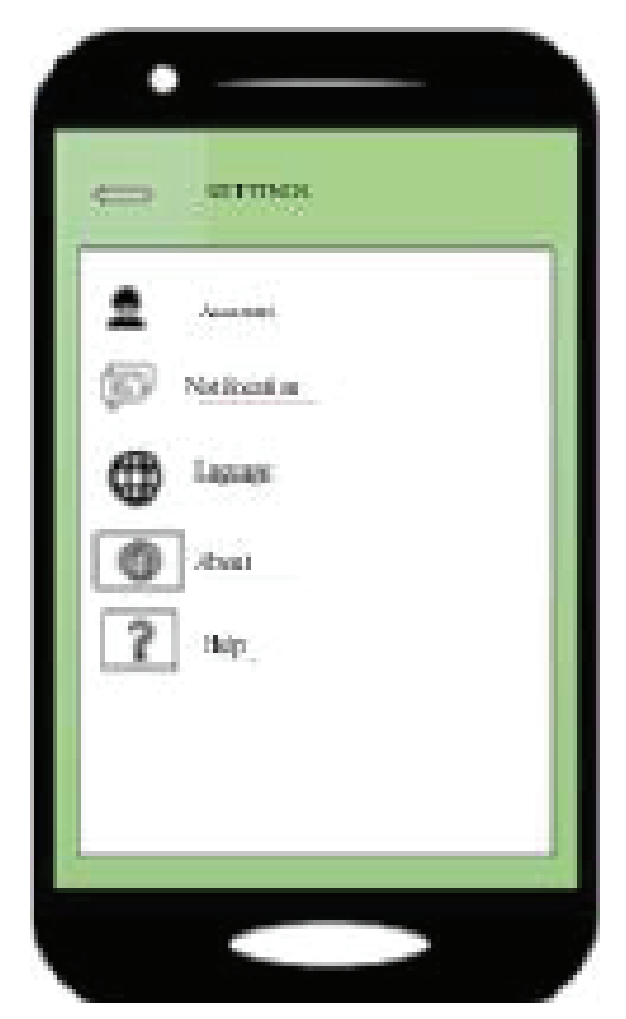

Figure 13: Interface settings.

\section{Discussion}

The results of this study found that the sprint design method is very appropriate to be applied to the mobile learning application that will be built[20, 21]. This method is very appropriate for building applications that are in accordance with user requirements. This method encourages application designers to design as needed[22, 23]. In this way, the application will tend to be used by the user because it suits the needs of the user.

\section{Conclusion}

This study concludes that, this model is very well used in building mobile learning applications easily and can be implemented quickly. Designing mobile learning applications by using the design sprint method can be built the right features for the user. The resulting features are based on an easy and simple design model so that it can produce a mobile learning application that is useful, easy to learn by displaying a simpler and easier to use. 


\section{Funding}

This work was supported by the Information Technology and Communication Education Department, Universitas Negeri Manado.

\section{Acknowledgement}

The authors would like to thank the Universitas Negeri Manado for their contribution and support to the research. They are also thankful to all the reviewers who gave their valuable inputs to the manuscript and helped in completing the paper.

\section{Conflict of Interest}

The authors have no conflict of interest to declare.

\section{References}

[1] I. Soleh. "Aplikasi M-Learning Berbasis HtmI5 Menggunakan," no. 1, pp. 61-66, 2015.

[2] S. ko. cecep furqon, St, aris sunandang, "Aplikasi Mobile Learning (M-Learning) Untuk Mata Kuliah Pengantar Teknologi Informasi Berbasis Java 2 Micro Edition (J2me)," wawasan IIm. Publ. AMIK garut, vol. 7, pp. 1-9, 2015.

[3] A. W. Purnamasari, A. A. K. C. Wiranatha, and N. M. I. M. Mandenni, "Aplikasi MLearning pada Platform Android," Merpati, vol. 2, no. 2, p. 219, 2014.

[4] M. I. Aripurnamayana, "Rancangan Dan Pembuatan Mobile Learning Berbasis Android (Studi Kasus: Pembelajaran Sejarah Di Smp )," J. Inform. Univ. Gunadarma, vol. 7, pp. 1-9, 2012.

[5] H. Rizal, S. Adhy, and P. W. Wirawan, "Perancangan Dan Pembuatan Mobile Learning Interaktif Berbasis Android Dengan Metode Personal Extreme Programming," vol. 2, no. 3, pp. 1-10, 2013.

[6] A. P. Putera et al., "Aplikasi M-Learning Berbasis Windows Phone Untuk Jurusan Teknologi Informasi," Merpati, vol. 3, no. 2, pp. 87-95, 2015.

[7] I. M. Wijayanto2, Arif Wibisono3, "Mobile-learning (m-learning)," 2014.

[8] S. Arrohman, "Konferensi Nasional,Inovasi dan Technopreneurship“ IPB International Convention Center, Bogor, 18-19 Februari 2013," Res. Bus. DIPONEGORO Univ. Dedic. Indones. Young Technopreneur To Build Up Bright Nation, no. Mkk 2308, pp. 18-19, 2013. 
[9] C. Paper, "Kajian Design Thinking®: Proses Metakognisi dalam Pelaksanaan Proyek Desain Produk (Studi Kasus Proyek Studio Desain Produk ber," no. May, 2014.

[10] J. R. Batmetan Suyoto, J. D. C. L. Suares, "An Empirical Investigation on Customer Behavior to Adopt Mobile Commerce among the $Y$ Generation in Indonesia", Sriwijaya International Conference On Engineering, Science \& Technology [SICEST 2016], 2016

[11] L. Madeso, D. R. Kabo, J. R. Batmetan, " Rancang Bangun Sistem Pakar Penentuan Status Gizi Pada Balita Menggunakan Metode Forward Chainning”, E-Jurnal UNSRIT, vol.2

[12] J. R. Batmetan, V. R. Palilingan, " Higher Education Students" Behaviour to Adopt Mobile Learning", IOP Conference Series: Materials Science and Engineering, 2018, vol. 306, Issue 1, pp. 012110 (2018)

[13] V. R. Palilingan, J. R. Batmetan, " Incident Management in Academic Information System using ITIL Framework", IOP Conference Series: Materials Science and Engineering, 2018, vol. 306, Issue 1, pp. 012110 (2018)

[14] M. L. Tompodung, F. Supit, J. R. Batmetan, " Rancang Bangun Aplikasi Sensus Penduduk Berbasis Android", Buletin Sariputra, 2017, vol.7, pp. 57-61

[15] S. M. Jacob and B. Issac, "Mobile Learning Culture and Effects in Higher Education," IEEE Multidiscipline. Eng. Educ. Mag., vol. 2, no. 2, pp. 19-21, 2007.

[16] S. Online courses, A. Abu-al-aish, and S. Love, "Factors Influencing Students " Acceptance of M-Learning: An Investigation in Higher Education," Int. Rev. Res. Open Distance Learn., vol. 14, no. 5, pp. 82-107, 2013.

[17] K. F. Hashim, F. B. Tan, and A. Rashid, "Adult learners" intention to adopt mobile learning: A motivational perspective," Br. J. Educ. Technol., pp. 1-10, 2014.

[18] S. M. Jacob and B. Issac, "The Mobile Devices and its Mobile Learning Usage Analysis," in Proceedings of the International Multiconference of Engineers and Computer Scientists, 2008, vol. I, pp. 19-21.

[19] J. P.-B. Mohamed Ally, "What is the future of mobile learning in education囚?," RUSC - Rev. Univ. y Soc. del Conoc. Univ. Knowl. Soc. J., vol. 11, no. 1, pp. 142-151, 2014.

[20] K. Mac Callum and L. Jeffrey, "The influence of students â€TM ICT skills and their adoption of mobile learning,” Australas. J. Educ. Technol., vol. 29, no. 3, pp. 303-314, 2013.

[21] D. H. Rif"ati, "Developing Of Electronic Teaching Material Based On Mobile Learning In The Wave Subjects Pengembangan Bahan Ajar Elektronik Berbasis Mobile Learning Pada Matakuliah Gelombang," J. Pendidik. Fis. Indones., vol. 11, no. 2, pp. 142-147, 2015. 
[22] N. R. Akhsan, "Investigating the Benefits of Mobile Phone Technology toward the Teaching and Learning Practices at Higher Schools," Ahmad Dahlan J. English Stud., vol. 2, no. 2, pp. 14-22, 2015.

[23] S. Johan Reimon Batmetan, Jaime Da Costa Lobo Suares, "An Empirical Investigation on Customer Behavior to Adopt Mobile Commerce among the $Y$ Generation in Indonesia," in Sriwijaya International Conference on Engineering, Science and Technology 2016 (SICEST 2016), 2016, pp. 333-337. 